\title{
Determinants of Audit Service Quality Perceptions of Supervisory Directors in Dutch Corporations
}

\author{
Asmerom Atewebrhan Ghebremichael \\ National Commission for Higher Education of Eritrea \\ E-Mail: asmerom.ateweberhan@gmail.com
}

\begin{abstract}
The purpose of this study is to investigate the effect of key quality attributes in the audit context on supervisory directors' assessment of audit quality. To this end, we identified, through survey questionnaires, audit quality attributes and dimensions (in terms of both their technical and service dimensions) based on the perception of supervisory board members in a sample of large and medium Dutch corporations. Factor analysis of the audit quality attributes produced four quality dimensions related to the core outcome of the audit service (auditor competence and independence) and five quality dimensions related to the relational (service) aspect. The paper, further, discusses the influence of these quality dimensions on the assessment of overall audit quality. The findings indicate that the technical and functional quality dimensions identified in this study do influence supervisory directors' perception of overall audit quality. The findings have both theoretical and policy implications. Our emphasis on supervisory board members, as current de jure and de facto clients of auditors, is a unique contribution of this study.
\end{abstract}

Keywords: Service Quality, Audit Quality, Supervisory Directors, Functional Quality, Technical Quality, Auditor Independence, The Netherlands

\section{INTRODUCTION}

Audit quality has been a fertile research area for the last two decades (Duff 2004; Watkins, Hillison, and Morecroft 2004; Warming-Rasmussen and Jensen 1998). Perhaps one of the most important developments affecting audit quality is that the supervisory board of directors 1 acts as the auditor's de facto and de jure client. ${ }^{2}$ These developments have important implications for audit firms that operate in a market that is dominated by a few seemingly oligopolistic firms with market power and whose main product - the audit of financial statements — is mature (Elliott and Parlays 1997). 
As a result, the environment in which audit firms operate can be characterized by fierce competition and pressure on fees (Duff 2004; Beattie and Fearnley 1998). Otherwise stated, on the one hand, audit firms are fighting for new clients and trying to snatch clients from competitors (Addams and Davis 1994); on the other, clients have started to tender their audit offer as well as engage in fee reduction negotiations with their auditors (Beattie and Fearnley 1998) with a potential for auditor change. To compete in this environment, audit quality has become more important than ever.

Several definitions of audit quality exist, depending on stakeholders' opinions of what the audit quality construct encompasses. Investors consider that audits are of high quality if the financial statements are free of material misstatements and if auditors give a warning signal if a company is in financial difficulties (Carson, Fargher, Geiger, Lennox, Raghunandan, and Willekens 2013). In line with this, one of the prevailing definitions of audit quality implies that (1) auditors discover material misstatements in the financial statements (auditor competence); and (2) that these misstatements are reported to the relevant parties (auditor independence) (DeAngelo 1981). However, as for the external users of the audit service the only observable outcome of the audit is the audit report, these two dimensions remain largely unobservable (Francis 2004). Furthermore, although previous research has revealed differences in audit quality depending on audit firm size, ${ }^{3}$ this criterion becomes less helpful if the audit firms are of the same size. Lastly, Tendello and Vanstraelen (2005) have stated that the technical capability of auditors is presumably consistent. In view of these remarks, it comes as no surprise to observe that audit firms are focusing more on the service dimension of quality in an attempt to differentiate themselves from their competitors (Duff 2004). For audit firms, service quality may be particularly important in to retain established and attract new clients. It is also crucial in attracting non-audit services in markets that do not prohibit the provision of such services. Indeed, research in service marketing indicates that quality service is a strategic tool that companies can use to influence both market share and profitability (e.g., Zeithaml et al. 2002; Zeithaml 2000; Cronin et al. 2000; Sweeney et al. 1997; Zeithaml et al. 1996; Richard and Allaway 1993).

The two research questions we pose in this study are as follows. According to the perception of the supervisory directors of Dutch corporations, what are the attributes and dimensions that define audit quality? What are the determinants of perceived overall audit quality?

To answer these research questions, we conducted an extensive literature review on the economics of auditing, audit quality and service marketing. We administered a 
survey to supervisory directors in medium and large corporations in the Netherlands. We quantitatively analyzed the data, then present and discuss the findings.

\section{LITERATURE REVIEW AND HYPOTHESES DEVELOPMENT}

\section{Defining Quality}

Researchers have proposed a variety of definitions of service quality, which means different things to different people. Grónroos (1990) and Zeithaml et al. (1990) argue that in the marketplace, consumers' judgement is the only one that counts when defining a quality construct. Accordingly, they define quality as the extent to which a product or service meets and/or exceeds a customer's expectations. Boshoff, Mels, and Nel (1994) stated that customer perceptions are an important consideration in the debate over what constitutes quality. This is intuitively appealing because when specifications are developed by managers rather than consumers, the definition ceases to be objective. Consumers, in contrast, can judge how well the product or service has met their expectations. Thus, the prevailing definition of quality in the service industry is "meeting and/or exceeding customers' expectations" (Reeves and Bednar 1994: 423).

This definition of quality makes it possible to capture critical subjective factors like courtesy, helpfulness and confidence. This definition has also the advantage of applicability across a wide variety of industries (see for example, Lu, Berchoux, Marek, and Chen 2015; Sanjuq 2014; Markovic and Raspor 2010; Mosahab, Mahamad, and Ramayah 2010). Moreover, it is an externally focused definition of quality that allows service providers to account for and respond to increasing expectations from their customers.

\section{Audit Quality}

Audit quality has been one of the most important issues facing the audit profession. Despite its importance and the approaches used to examine it, there is no explicit definition of audit quality and little is known about the factors that are perceived to affect it (van Raak and Thürheimer 2016). The most frequently used definition of audit quality in the academic literature is "the market-assessed joint probability that an auditor will both (a) discover a breach in the client's accounting system, and (b) report the breach" (DeAngelo (1981, p. 186). According to this definition, audit quality is a function of an auditor's perceived competence and independence. 
DeFond and Zhang (2014) take a regulatory view, defining define audit quality as "greater assurance that the financial statements faithfully reflect the firm's underlying economics, conditioned on its financial reporting system and innate characteristics" (p. 276). Donovan, Frankel, Lee, Martin, and Seo (2014) take a more client/auditor-oriented view and propose that audit quality should be determined by client preferences and audit firm's efficient provision of services for which they hold a competitive advantage.

Like in many other services, audit quality is characterized by a strong ambiguity that makes it hardly observable, definite, and measurable (Causholli and Knechel 2012; Wooten 2003; Herrbach 2001). As a professional service sector, audit service can be characterized by intangibility of output for which precise specifications for the uniform quality of its output are difficult, if not impossible to set (Krishnan and Schauer 2000; Knapp 1991). It is also, to a large extent, characterized by inseparability of the provision and consumption of the service. And finally, different users of, and parties to, the service may have different expectations and perceptions for the same service. Taken together, these characteristics make it impossible for users such as supervisory directors to make an ex ante assessment of factual audit quality because of limited access to important variables (van Raak and Thürheimer 2016; Knapp 1991). However, Brown and Swartz (1989) argue that in professional services, clients do evaluate quality despite the difficulty.

This review of the literature indicates that quality is a multidimensional construct with broad technical and functional dimensions (Markovic and Raspor 2010; Mosahab, et al., 2010; Lehtinen and Lehtinen 1991; Grónroos 1984). The technical outcome of the service is what consumers receive as a result of their interactions with a service provider. Consumers' perception of quality with regard to the final outcome of the service is thus called technical quality. However, the customer is also interested in how the service was or is being provided. How the waiters behave in a restaurant, the courtesy of flight attendants, the equipment used by a transportation company in the delivery of goods, the way auditors communicate with their clients, the responsiveness of business consultants to the problems of their clients, for example, all affect the customer's view of the service. Grónroos (1984) referred to this dimension of service quality as its functional quality. In this study, the audit quality construct is measured in terms of its technical and functional aspects.

In the economics of auditing literature, researchers have concentrated on the technical dimension of audit quality (DeAngelo 1981; Watts and Zimmerman 1981). These researchers try to link technical audit quality to the risk of detecting and disclosing anomalies in the financial statements (Carson et al., 2013). The definition 
of audit quality as the likelihood that material misstatements in the financial reports will be discovered (auditor competence) and that the auditor will report these misstatements (auditor independence) stems from the role of the auditor in minimizing the cost associated with agency conflict (Watkins et al. 2004). Following this argument, this study defines technical audit quality as supervisory directors' perception of auditor's competence and independence.

The economics of auditing literature do not consider the relational aspect that is inherent to the provision of audit services; there seems to be a continuous relationship between a client and an audit firm. Therefore, the definition of quality in terms of the agency problem should be integrated with the functional aspect of quality. This functional dimension has been extensively covered in the marketing literature; the most notable of such studies being those of Parasuraman et al. (1985, 1988). Parasuraman et al. (1985) suggest that customers assess overall service quality based on five generic dimensions: tangibles, reliability, responsiveness, assurance and empathy. They propose that each of these dimensions can be measured by identifying the relevant service attributes. Their studies led to the identification of 22 pairs of functional quality attributes designed to capture the five dimensions. The ideas of Parasuraman et al. $(1985,1988)$ have also been used to measure audit quality in studies by Duff (2004), Morton (1998), and Dassen (1995). The distinguishing characteristic of these studies is that perceptions of different users of the audit service are used to measure audit quality.

\section{Hypotheses Development}

Ensuring technical audit quality is one of the mechanisms for minimizing the effect of the agency problem caused by information asymmetry. If information is not made transparent, it is a weapon in the hands of the agents (managers) that could be wielded against the principal's interests (Jensen and Meckling 1976). As representatives of the principal (shareholders/stakeholders), it is an essential part of the supervisory board's oversight role to ensure the provision of an objective disclosure of financial information. This suggests that a higher perception of, and performance of, the technical quality dimensions will have a positive effect on the supervisory directors' assessment of overall audit quality. Dassen (1995) found a positive relationship between the detection ability of auditors (auditor competence) and overall assessment of audit quality for clients and bankers in the Netherlands. The marketing literature also suggests a positive influence of technical quality on the assessment of overall quality (Sweeney et al. 1997). Therefore, we hypothesize that: 
H1: Technical (auditor competence) audit quality dimensions will have a positive influence on perceived overall audit quality.

Functional quality attributes arise as the result of service provision, when the service provider continuously interacts with the client. This interaction, obviously, affects the client's assessment of how well or poorly the service was provided. Theoretical and empirical studies (Morton 1998; Dassen 1995; Bojanic 1991; Lehtinen and Lehtinen 1991; Parasuraman et al. 1988 and 1985; Grónroos 1984) have argued for a positive relationship between functional audit quality attributes and the overall assessment of audit quality. Indeed, functional quality may compensate for technical quality problems (Saleh and Ryan 1991). Thus, we hypothesize that:

H2: Functional quality dimensions will have a positive influence on perceived overall audit quality.

In formulating our hypotheses we did not look at auditing as a service and the context in which it is rendered. We refer here to the independence of auditors, which is a unique attribute of the audit service. Independence is the second technical audit quality dimension of DeAngelo's (1981) conceptualization of two-dimensional audit quality. Supervisory boards, as overseers of the principal's (stakeholders') interest, are expected not only to appreciate, but also to demand the independence of their auditor. Contemporary corporate governance codes and best practices also require the audit committee to recommend the (re)appointment of the external auditor and ensure his independence (for example, the Tabaksblat Committee 2003, Smith Committee of the UK 2003). Dassen (1995) found that auditor independence is not appreciated by executive directors (management). However, for supervisory directors auditor independence is intuitively highly desirable as it is an important instrument in their control role. Hence, it seems logical to expect supervisory directors to assess audit quality as high for those auditors that they perceive as independent. Thus:

H3: Perceived auditor independence will have a positive influence on assessed overall audit quality.

\section{RESEARCH FRAMEWORK}

Figure 1 depicts the research framework proposed this study. It identifies the relationship among technical (competence) audit quality, functional audit quality, auditor independence, and perceived overall audit quality. 


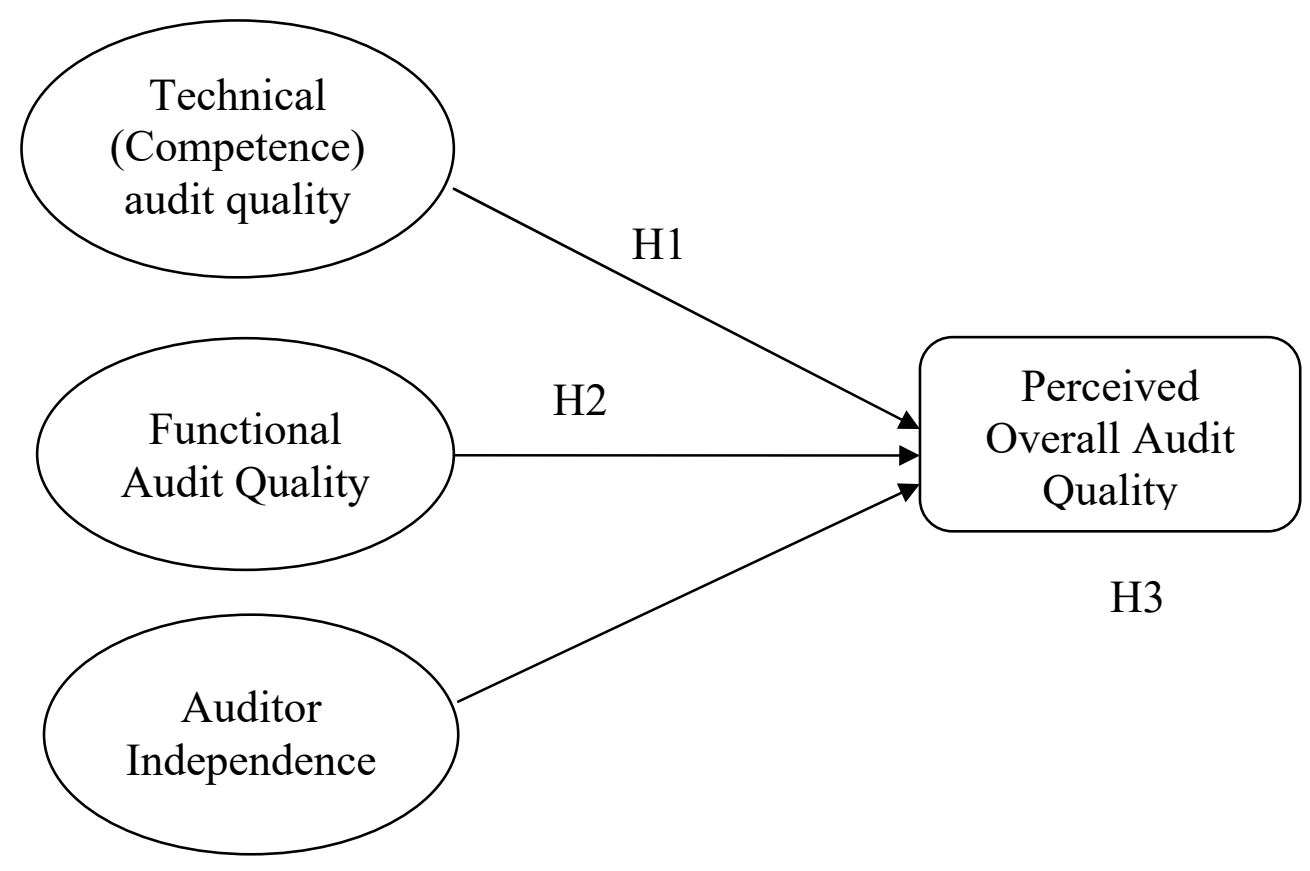

Figure 1 The research framework

\section{RESEARCH METHODOLOGY}

\section{Attributes of Audit Quality}

We have stated, based on the literature review, that service quality is a multidimensional construct with technical and functional dimensions. The first step in the measurement of audit quality is, therefore, the identification of audit quality attributes. An integrated literature review in the economics of auditing and audit expectation-gap studies has enabled us to identify attributes of auditor competence (detection ability) and independence (willingness to report). Furthermore, from the behavioral audit quality and marketing literature we identified those attributes that determine the relational aspect of the audit service process (functional dimension). Therefore, we measure audit service quality in terms of auditor competence and independence as well as functional dimensions.

As recommended by Churchill (1979) we recruited an experience group in the attributes identification procedure. A similar methodology was followed by WarmingRasmussen and Jensen (1998) in which a user perspective was used to identify the list of attributes that may influence audit quality. Warming-Rasmussen and Jensen (1998) identified their audit quality attributes through a dialogue with four representatives of external user groups (shareholders, financial journalists, managing directors, and 
public accountants). In this study the attributes we identified were also presented to two highly experienced supervisory directors and seven audit partners for discussion of their relevance to supervisory directors' perception of audit quality. A total of 76 attributes of audit service quality were presented to the experience group for discussion. The experience group indicated that the attributes identified have different levels of relevance for supervisory directors. Accordingly, we selected the items that most of the interviews identified as highly (and moderately) relevant.

The discussion on the attributes identified from the literature together with some new attributes suggested by the interviewees resulted in 43 attributes. Subsequent discussions with two auditing professors, and a pre-test of the questionnaire resulted in nine additional attributes for a total of 52 (appendix 1). Out of the 52 attributes, 25 are related to the technical dimension (auditor competence and independence) and 27 to the functional dimension.

\section{Measurement of Audit Quality}

Several service marketing studies operationalize theoretical frameworks and introduce methodologies for the measurement of service quality by defining quality (e.g., Cronin and Taylor 1992; Bolton and Drew 1991; Parasuraman et al. 1985, 1988, 1991). The definition of service quality as "meeting and/or exceeding customers' expectations" has created gaps in the (SERVQUAL) model for the measurement of service quality (Parasuraman et al. 1985, 1988, 1991; Zeithaml et al. 1988). According to this model, service quality can be assessed by comparing customers' expectation of the service prior to the service encounter and their perceptions of the actual service delivered. The resulting difference between performance and expectation indicates the perceived level of quality.

Parasuraman et al. developed the gap model after a rigorous procedure of attribute identification and purification (1985, 1988, and 1991). The gap model is the most popular instrument for measuring service quality. Nevertheless, several researchers, and indeed the developers of the instrument have recognized that both the instrument and the conceptualisation of service quality may benefit from further refinement (e.g., Woo and Ennew 2005; Stank, Goldsby, and Vickery 1999; Francis 1996; Richard and Allaway 1993; Teas 1993; Cronin and Taylor 1992; Babakus and Boller 1992). Peter, Churchill, and Brown (1993) argue that the gap model needs more than a simple modification if it is to evaluate service quality.

Some researchers have adapted the items in the gap model to develop alternative measures that overcome the problems associated with the conceptualization of service quality as a difference score. Cronin and Taylor (1992) dropped the expectations 
component of the gap model and apply only its performance component. Cronin and Taylor (1992) claim that the performance-only instrument (which they call SERVPERF) explains more of the variations in the global (overall) measure of service quality. Following Cronin and Taylor (1992) this study measures the audit quality construct based on the perception of supervisory board members about their auditors' performance on the technical and functional audit quality attributes. Performance on quality attributes as a measure of audit service quality has been previously employed by Morton (1998) and Dassen (1995).

\section{Questionnaire}

The research design involves a highly structured self-administered questionnaire mailed to a cross-section of supervisory directors of public and non-public companies. The questionnaire is designed to generate data on the perceptions of supervisory directors about their auditors' performance with regard to the 52 audit quality attributes. In addition, we sought supervisory directors' opinion on the independence of their auditors. The assessment is made using two experimental questions on auditor independence in which we asked supervisory directors to indicate whether their auditors would issue a qualified opinion or report to the audit committee if and when certain irregularities discovered were not resolved by the management as per the auditors' requirements. Lastly, we intended to obtain supervisory board members' perceptions of the overall quality of their auditors. This is done through a single scale assessment. All questions were measured on a 7-point Likert scale, ranging from "strongly agree" (7) to "strongly disagree" (1).

The questionnaire was pre-tested on four supervisory directors to see if it was realistic, understandable, and easy to complete. The participants in the pre-test offered feedback on the difficulty they encountered in filling in the questionnaire. All the respondents agreed that the questionnaire was realistic.

\section{Sample and Response}

The EURONEXT-Amsterdam and the REACH (Review and Analysis of Companies in Holland) databases were used to select sample supervisory directors. For the purpose of identifying the names and addresses of these supervisory directors, 382 large listed and non-listed companies were selected (151 listed companies from the EURONEXT-database and 231 from the REACH-database). Each participant received an envelope containing the questionnaire, a cover letter, a self-addressed reply card, and a self-addressed return envelope. The survey instrument was sent to supervisory directors of these companies and 69 usable responses were returned. 
The background questions revealed that the respondents have quite significant experience as supervisory directors. More than half (about 54 percent) have served as supervisory directors in more than five companies. In addition, 52 percent of the respondents have been supervisory directors for more than five years. About 30 percent are board chairs. Their areas of expertise and knowledge of business administration are rich. About 36 percent of the respondents are experts in accounting and finance. Almost 50 percent have a reasonable knowledge of accounting and finance in addition to their specialities, which include general management, law, human resource management, marketing, engineering, information technology, insurance, and real estate investment and development.

\section{RESULTS}

\section{Factor Analysis}

We conducted factor analysis on the 52 attributes to reduce them to a manageable number of quality dimensions which are needed for further analysis. The factor analysis was performed separately for the 25 technical attributes and the 27 functional attributes. Only variables with factor loadings above 0.45 are accepted as belonging to a factor.4 This yielded five functional and four technical quality factors which are the audit quality dimensions identified in this study. We used principal components analysis 5 because it provides uncorrelated factors which can, then, be used for further regression analysis, addressing the problem of multicollinearity assumption in regression analysis (Kim and Mueller 1994). However, conducting separate factor analysis for technical and functional attributes means that there may be multicollinearity between the resulting technical and functional factors. (See appendix 2 for information on multicollinearity between technical and functional quality factors.)

The statistical measures for suitability of the data for factor analysis are given in table 1. Bartlett's test of sphericity and KMO-MSA values indicate the appropriateness of the variables for factor analysis. In both the technical and functional attributes, the KMO-MSA is in the high range, giving way for quality interpretations. ${ }^{6}$ 
Table 1 Suitability of Variables (attributes) for Factor Analysis

\begin{tabular}{lcc}
\hline \multicolumn{1}{c}{ Test } & $\begin{array}{c}\text { Functional Quality } \\
\text { Attributes }\end{array}$ & $\begin{array}{c}\text { Technical Quality } \\
\text { Attributes }\end{array}$ \\
\hline KMO-MSA & 0.80 & 0.86 \\
Bartlett's Test of Sphericity & $926.288(0.000)$ & $1431.640(0.000)$ \\
No. of variables & 23 & 23 \\
No. of factors & 5 & 4 \\
Rotation method & Equamax & Equamax \\
\hline
\end{tabular}

The factors are subjectively labelled to find an explanation that best reflects the properties shared by the set of variables (attributes) within each factor. An attempt has been made to reduce the subjectivity of the factor labelling by involving two more people (an academician and a practitioner) in the labelling process. The panels in the table list the reliability of the factors as measured by Cronbach's alpha (de Vaus 1996) and the variance accounted for by the factors. The minimum 0.7 alpha rule of thumb was violated by two functional factors (easy-to-deal-with and accessibility). Four functional attributes out of 27 and two technical attributes out of 25 were eliminated because they had weak (low) factor loadings. The factor solution for the technical performance attributes accounted for a variance of 74.6 percent. The factor solution for the functional performance attributes accounted for a variance of 66.1 percent. The factors are shown in tables 3 and 4 for technical and functional attributes, respectively. The factor solutions are presented and discussed in the sub-sections following the tables.

\section{Functional Factors}

\section{- Reliable Audit Process}

This factor is concerned with the supervisory directors' perceptions of the auditor's personal reliability. The variables included in this factor pertain to the auditor's accuracy and dependability with regard to working papers, auditor knowledge, audit effectiveness, time management, and clarity of communication. In the service quality literature (see e.g., Parasuraman et al. 1988), reliability is concerned with the dependability and accuracy of the service. Thus, this factor is similar to the reliability factor of the SERVQUAL model (Parasuraman et al. 1988). It is also related to the competence dimension of technical audit quality albeit not in the 
sense of the auditor's traditional duties.

Table 2 Functional Factor Solution for Performance-Only Variables

\begin{tabular}{lccc}
\multicolumn{1}{c}{$\begin{array}{c}\text { FACTORS }^{\mathrm{a}} \\
\text { Variables }^{\mathrm{b}}\end{array}$} & $\begin{array}{c}\text { Factor } \\
\text { Loadings }\end{array}$ & $\begin{array}{c}\text { Cronbach's } \\
\text { Alpha }\end{array}$ & $\begin{array}{c}\text { Cumulative } \\
\text { Variance }\end{array}$ \\
\hline 1. RELIABLE AUDIT PROCESS & & & \\
Maintain error free record & 0.749 & 0.87 & \\
Knowledge to answer supervisory board's questions & 0.687 & & \\
Audit effectiveness & 0.650 & & \\
Meet deadline & 0.634 & \\
Responsive to the needs of supervisory boards & 0.589 & \\
Ability to be expressive & 0.554 & \\
\hline
\end{tabular}

2. COMPANY AND INDUSTRY KNOWLEDGE (Knowledge Dissemination)

Knowledge of internal and external environment of client

0.740

0.86

31.0

Use of client's internal audit

0.686

Provisions to keep clients up-to-date

0.650

Regulatory Knowledge

0.618

Use of international contacts and resources

0.588

Active participation in the audit by audit partner

0.587

Industry specialist

0.468

3. EASY-TO-DEAL-WITH

Reliable in handling client service problems

0.772

0.69

44.4

Responsive to the needs of executive directors

0.714

Reasonable audit fee

0.470

\section{PROVIDING QUALITY INSIGHTS}

Comments on the quality of forecasts and targets

0.890

0.78

55.7

Comments on the quality of executive directors

0.882

Bench mark comparisons on the quality of internal

0.593 control

\section{ACCESSIBILITY}

A provision for private session

0.640

0.58

66.1

Good overall reputation

0.622

Accessibility of Auditor to executive directors

0.618

Accessibility of Auditor to supervisory boards

0.458 
Table 3 Technical Factor Solution for Performance-Only Variables

\begin{tabular}{lccc}
\hline \multicolumn{1}{c}{$\begin{array}{c}\text { FACTORS } \\
\text { Variables }^{\mathrm{b}}\end{array}$} & $\begin{array}{c}\text { Factor } \\
\text { Loadings }\end{array}$ & $\begin{array}{c}\text { Cronbach' } \\
\text { s Alpha }\end{array}$ & $\begin{array}{c}\text { Cumulativ } \\
\text { e Variance }\end{array}$ \\
\hline 1. WHISTLE BLOWING (Public Agent) & 0.917 & 0.95 & 24.5 \\
Report material management fraud to the public & 0.912 & & \\
Report illegal acts to the public & 0.909 & & \\
Report material deficiencies in internal control to the public & 0.881 & \\
Report earnings management to the public & 0.861 & \\
Report material employee fraud to the public & 0.839 & \\
Report going concern problems to the public & 0.820 & & \\
Report material errors in the financial statements to the & & & \\
public & &
\end{tabular}

2. DETECTION AND REPORTING OF FRAUD AND ILLEGAL ACTS

Report material management fraud to the supervisory board $\quad 0.881$

$0.93 \quad 45.1$

Report illegal acts to the supervisory board $\quad 0.847$

Report material employee fraud to the supervisory board $\quad 0.725$

Detect illegal acts $\quad 0.719$

Detect material management fraud $\quad 0.685$

Detect material employee fraud $\quad 0.623$

Report going concern problems to the supervisory board $\quad 0.575$

3. INTEGRITY IN FINANCIAL REPORTING PROCESS

$\begin{array}{llll}\text { Report material deficiencies in internal control to the } & 0.807 & 0.91 & 65.1\end{array}$ supervisory board

Report material errors in the financial statements to the $\quad 0.741$ supervisory board

Detect earnings management in the financial statements $\quad 0.708$

High level of integrity $\quad 0.686$

Detect material deficiencies in internal control $\quad 0.682$

Report earnings management to the supervisory board 0.643

Detect going concern problems $\quad 0.612$

Detect material errors in the financial statements $\quad 0.592$

4. INDEPENDENT ATTITUDE

Independent of all stakeholders

0.814

n.a.

74.6

Note: $\quad{ }^{\mathrm{a}}$ Labels in capital letters are factors extracted.

${ }^{\boldsymbol{b}}$ The statement of the variables are abbreviated in order to make them fit to the table (For detail, see appendix 1). 


\section{- Company and Industry Knowledge (Knowledge Dissemination)}

This factor is also related to the audit firm's overall reliability in terms of its knowledge about the client's business and regulatory matters. The supervisory directors also perceived the sharing of this knowledge with the client to be part of this factor. Variables loading high in this factor include knowledge of the internal and external environment of the client, use of client's internal audit, provisions to keep clients up to date, regulatory knowledge and auditor industry specialization.

\section{- Easy-to-deal-with}

This factor consists of only three variables. This factor also has a slightly lower alpha of 0.69 compared to the greater than 0.70 alpha rule of thumb. The factor reflects a combination of auditor's reliability in handling service problems and responsiveness to the executive directors' needs. It also shows the perception of the supervisory directors with regard to the reasonableness of the audit fee. Thus, the lower reliability and the variety of the variables in the factor mean that care needs to be taken in interpreting this factor.

\section{- Providing Quality Insights}

The essence of this factor is in the proactive contribution of the auditor over and above the traditional role of uncovering misstatements in the annual reports. It is concerned with the comments on the quality of the executive management of the auditee company and the quality of the information system it adopts. It contains three high-loading and reliable variables (alpha of 0.78 ).

\section{- Accessibility}

This factor represents the auditor's availability for a discussion with the directors of the client company. It includes variables such as a provision for a private session with the supervisory board and accessibility to both supervisory and executive directors. It is similar to the "empathy" dimension of the SERVQUAL model (Parasuraman et al. 1988). The variables in this factor have the lowest reliability measure with 0.58 alpha.

\section{Technical Factors}

\section{- Whistle Blowing (Public Agent)}

This factor includes variables concerning the auditor's role in disclosing, to the public, detected errors and irregularities in the auditee's financial information as well 
as management's integrity. These errors and irregularities pertain to fraud, illegal acts, deficiencies in internal control, earnings management, going concern problems, and inaccuracies in the financial statements.

\section{- Detection and Reporting of Fraud and Illegal Acts}

This factor represents the auditor's role in the detection and reporting of fraud and illegal acts. Unlike the first technical factor, the reporting is to the company's supervisory board, and not to the public. Not surprisingly, supervisory directors perceived a relationship between the detection and reporting of fraud and illegal acts on one hand and the reporting of going concern on the other. Perhaps supervisory directors associate fraud and illegal acts by management with the company's going concern problems. Alternatively, they consider these irregularities to have a similar magnitude of effect on the company's future.

\section{- Integrity in Financial Reporting Process}

This factor represents the auditor's role in the detection of problems with the internal control and the annual financial statements, and the reporting of these problems to the supervisory board. The latter is captured by the variables "errors in the financial statements" and "earnings management." The factor also contains a variable on the auditor's overall integrity.

\section{- Independent Attitude}

This is a unique technical audit quality factor in the sense that it is a single variable loaded into a factor by itself. This variable concerns the auditor's independent attitude in relation with the stakeholders of the client's company. Apparently, supervisory directors perceive this factor to be uniquely identifiable. It is related to the second dimension of DeAngelo's (1981) conceptualization of audit quality. This is one way to measure auditor independence in our regression analysis.

\section{Discussions on the Dimensions of Audit Quality}

The factor solution revealed that supervisory directors drew a distinction between an auditor's technical competence related to his traditional duties (the accuracy of the annual accounts and the effectiveness of internal control) on the one hand, and nontraditional duties (the detection and reporting of fraud and illegal acts) on the other. Attributes on auditor independence resulted in two dimensions. Supervisory directors distinguished auditor's complete independence (both from executive and nonexecutive directors) on the one hand, and independence from just executive directors 
on the other. Complete auditor independence is realized when the auditor is free to report irregularities to the public, making him an agent of both the supervisory board and the public. Auditor independence is limited when he reports only to the supervisory board in which case the auditor is considered as supervisory boards' watchdog. The level of auditor independence that is appreciated by supervisory directors is revealed in our regression analysis on the determinants of overall audit quality.

The "reliable audit process" factor is concerned with an auditor's dependability and accuracy during service provision. It pertains to auditor's personal characteristics as well as the audit firm's reputation and quality assurance procedures. This factor is similar to the reliability and assurance factors identified in the service marketing literature (Parasuraman et al. 1988). It is also related to the competence dimension of technical audit quality in that it contributes to improved performance of the auditor's traditional duties. The "providing quality insights" factor concerns the contribution of the auditor over and above his traditional duties especially in matters of corporate governance. The "company and industry knowledge" factor is related to the audit firm's overall reliability in terms of knowledge about the client's business and regulatory matters that should be shared with the client. The "easy-to-deal-with" factor reflects the importance of the auditor's sensitivity to the executive directors' needs; "accessibility" represents the auditor's availability for discussions with the directors of the client company including a provision for private sessions to supervisory boards. The easy-to-deal-with and accessibility dimensions are similar to the responsiveness and empathy factors in the service marketing literature (Parasuraman et al. 1988).

A comparison of the dimensions identified in our study with those of related behavioural audit quality studies as well as the "generic" service quality dimensions of Parasuraman et al. (1988) revealed some interesting results. Although some of the factors identified in this study also appeared in several audit quality and service marketing studies, others were unique to this study. This can be explained by the measurement models used, respondent groups, timing of the studies, and the operationalization of variables between this and the comparable studies.

The "reliable audit process," "company and industry knowledge," and "accessibility" are factors that emerged in several studies (e.g., Duff 2004; Morton 1998; Warming-Rasmussen and Jensen 1998; Dassen 1995; Beattie and Fearnley 1995; Carcello et al. 1992). Although these factors are essentially contextual to the audit service, they are similar to the reliability, assurance, responsiveness, and empathy dimensions of Parasuraman et al. (1988). The "providing quality insights" factor in 
our study, which reflects the auditor's proactive involvement in terms of providing advice to supervisory directors on corporate governance, appeared as "provision of Non-audit services (NAS)," "partner-in-business," and "value-for-money" factors in studies by Duff (2004), Dassen (1995), and Beattie and Fearnley (1995). The "easyto-deal-with" factor is identified in Duff (2004) as "responsiveness."

The technical quality factors are comparable to those identified by Morton (1998) and Dassen (1995). However, this study revealed a distinction in the auditor's role about the integrity of the annual reports on one hand and fraud and illegal acts on the other. Only Warming-Rasmussen and Jensen (1998) and Dassen (1995) identified the auditor's public agent duty as openness in the audit report and whistle-blowing respectively. Also, integrity in financial reporting process dimension appears to be identified only by Morton (1998) and Dassen (1995) whereas the detection and reporting of fraud and illegal acts dimension was identified only by Dassen (1995). In general, few studies identified the technical audit quality dimensions compared to the functional dimensions which appeared in several behavioral audit quality and service marketing studies.

\section{Hypothesis Testing on the Determinants of Overall Audit Quality}

In the survey, respondents were asked to assess the overall quality of their auditors' (audit firms') service. This was done through a single measure of overall audit quality elicited in the questionnaire with a 7-point Likert scale rated from "poor" to "excellent." The descriptive statistics indicate that supervisory directors rated the quality of their auditors' rather high. The mean overall audit quality was 5.33. Previously, we hypothesized that this rating can be influenced by supervisory directors' assessment of the functional, technical, and independence quality dimensions (or variables). We used the regression model to test these hypotheses:

$$
O A Q_{x}=\quad c+a_{0} F A Q_{p x}+a_{1} T A Q_{p x}+a_{2} I N D_{p x}
$$

\section{Where:}

$\mathrm{OAQ}_{\mathrm{x}}=$ Overall audit quality statement for case $x$;

$\mathrm{c}=$ Constant;

$\mathrm{FAQ}_{\mathrm{px}}=\quad$ Functional audit quality factor score $p$ for case $x$;

$\mathrm{TAQ}_{\mathrm{px}}=\quad$ Technical audit quality factor score $p$ for case $x$;

$\mathrm{IND}_{\mathrm{px}}=\quad$ Independence statement (factor score) $p$ for case $x$;

The independent variables of the model are the quality dimensions identified by the performance-only model as well as two auditor independence variables. Moreover, based on the groupings of the independent variables, the regression model is applied at 
three levels: (1a) functional, technical and auditor-independence dimensions (variables) are selected at the same time; (1b) only technical and auditor-independence dimensions (variables) are selected; and (1c) only functional dimensions are selected. The reason for this is to identify those factors whose influence on overall audit quality was camouflaged by the multicollinearity between the functional and technical quality dimensions. Table 4 presents the results of the regression model at the three levels of the model (a, b, and c).

The table shows that the variables in the three levels of the model explain a significant variance of overall audit quality. The adjusted R-squared for all three levels are rather high. The highest prediction is acquired when all of the independent variables are selected at the same time (model a). The results in table 4 show that the determinants of overall audit quality are mainly related to the auditor's competence (detection ability) and independence. This pertains not only to errors and irregularities in the financial reporting systems but also to fraud and illegal acts. The auditor's personal character in terms of reliability (accuracy and dependability) in the service delivery process also appears to be important for supervisory directors. In general, the technical quality attributes are found to be the most important determinants of overall audit quality.

It should be noted, however, that there was significant multicollinearity between the "integrity in financial reporting process" and the "easy-to-deal-with" dimensions (see appendix 2). This multicollinearity has definitely masked the impact of the "easyto-deal-with" dimension on overall audit quality. In addition, there was some multicollinearity between the dimensions "independent attitude" and "company and industry knowledge." Consequently, the latter's impact was not revealed in model A. Model C shows that this is, indeed, the case as the "easy-to-deal-with" and the "company and industry knowledge" dimensions became significant predictors when only the functional dimensions are selected in the regression model. Thus, model C hints at the importance of these two functional dimensions in supervisory directors' assessment of overall audit quality.

All of the statistically significant dimensions influence overall audit quality in the hypothesized direction. Thus, the three hypotheses with regard to overall audit quality are supported. However, the auditor-independence variable "qualified opinion," although not significant, has the opposite impact on perceived overall audit quality. This is in contrast to the other two auditor-independence variables -- "independent attitude" and "bring to the attention of the supervisory board/audit committee" -- both of which are significant positive predictors of overall audit quality. This implies that the supervisory directors would rate overall audit quality high even when the auditor 
would not issue a qualified opinion when there is an unresolved material misstatement in the financial statements. Another independence variable (whistle blowing/public agent) also was not found to be a significant determinant of overall audit quality. This, again, seems to imply that, with regard to auditor independence, what supervisory boards want is for the auditor to be loyal to them while being perceived as independent by others.

Table 4 Determinants of Overall Audit Quality

\begin{tabular}{|c|c|c|c|c|c|c|}
\hline \multicolumn{7}{|c|}{ Model 1: Dependent is overall audit quality } \\
\hline \multirow[t]{2}{*}{ Performance-only factors } & \multicolumn{2}{|c|}{$1 \mathbf{a}$} & \multicolumn{2}{|l|}{$1 \mathbf{b}$} & \multicolumn{2}{|l|}{$1 \mathrm{c}$} \\
\hline & B & sig. & B & sig. & B & sig. \\
\hline (Constant) & 4.341 & $* * *$ & 4.396 & $* * *$ & 5.333 & $* * *$ \\
\hline $\begin{array}{l}\text { Integrity in financial reporting process } \\
\text { (H1) }\end{array}$ & 0.398 & $* * *$ & 0.476 & $* * *$ & - & - \\
\hline Independent attitude (H3) & 0.308 & $* * *$ & 0.379 & $* * *$ & - & - \\
\hline $\begin{array}{l}\text { Detection and reporting of fraud and } \\
\text { illegal acts }(\mathbf{H 1})\end{array}$ & 0.178 & $*$ & 0.198 & $* *$ & - & - \\
\hline $\begin{array}{l}\text { Bring to the attention of supervisory } \\
\text { board/ audit committee }(\mathbf{H 3})\end{array}$ & 0.167 & $* *$ & 0.157 & $* *$ & - & - \\
\hline $\begin{array}{l}\text { Reliable audit process (Auditor } \\
\text { reliability) }(\mathbf{H 2})\end{array}$ & 0.201 & $*$ & - & - & 0.492 & $* * *$ \\
\hline Company and industry knowledge (H2) & 0.054 & & - & - & 0.303 & $* *$ \\
\hline Easy-to-deal-with (H2) & 0.102 & & - & - & 0.347 & $* *$ \\
\hline Providing quality insights & 0.012 & & - & - & 0.145 & \\
\hline Accessibility & -0.139 & & - & - & 0.083 & \\
\hline Whistle blowing (Public agent) & 0.107 & & 0.093 & & - & - \\
\hline Qualified opinion & -0.076 & & -0.082 & & - & - \\
\hline Observations & 69 & & 69 & & 69 & \\
\hline F-value & 14.250 & $* * *$ & 16.180 & $* * *$ & 16.576 & $* * *$ \\
\hline Adj. R-squared & 0.493 & & 0.472 & & 0.407 & \\
\hline
\end{tabular}

$* * *, * *, *$ : Significance level at $0.01,0.05$, and 0.10 (two-tailed) respectively

Note: H1, H2, H3 in parentheses next to the variables indicate that these hypotheses are supported. 


\section{Discussions on the Determinants of Overall Audit Quality}

Supervisory boards appear to base their auditors' overall quality assessment on the technical, functional, and independence dimensions identified in this study. From the technical dimensions, integrity in financial reporting process in addition to the detection and reporting of fraud and illegal acts influence overall audit quality. Although the former dimension is self-evident in the audit profession, the latter is an area where the profession has been passive because of the difficulty of revealing irregularities resulting from fraud and illegal acts. It is also an area with great potential for auditor litigation.

From the functional dimensions, reliability of audit process, auditor's company and industry knowledge, and being easy-to-deal-with are the determinants of overall audit quality. The functional quality dimension "providing quality insights" is not found to be an important determinant of audit quality. One attribute of the reliableaudit-process dimension is time management. According to an auditor in our experience group:

The time factor is very important because not being on time causes many problems. When you are too late with management letters, letters to the audit committee or to the supervisory directors, it causes many problems. The board meeting concerning the annual financial statements is at a certain date and a week before that meeting the auditor should deliver the letter to the supervisory directors. When you are too late you do not allow them [the supervisory board] to prepare and this could be the cause of many service problems. In my experience during the last 15 years many problems between the auditor and the supervisory directors were caused by not delivering at the right moment.

On one attribute of auditor's company and industry knowledge, another auditor inn our experience group commented:

This is a very important issue because sometimes there are company specific accounting rules. It becomes difficult to audit these companies if you have not worked with the industry. I believe this is definitely expected by the supervisory directors. I was recently involved in a business proposal and the issue of partner experience with the business was almost on top of the list of the supervisory directors' requirements. Because if you don't understand the industry, how will you be able to test whether a provision for obsolete materials is correct or not. If you are involved in the audit of a semiconductor business and you don't have a clue of how the industry works then you can't audit the company.

The relevance of the "easy-to-deal-with" dimension has developed with the growing importance of audit committee responsibilities. A member of the experience 
group put it this way:

What I find in practice in the Netherlands is that we now have more audit committees. In the past, what was typical for a large audit client is that the auditor meets with the executive board regularly, but only once a year with the supervisory directors. Now that we are growing towards the situation where we meet with the audit committee frequently, you see that the relationship is improving and opening up and the quality of communication improves. It is also easier to be frank in the discussion.

From the auditor independence dimension, the auditor's independent attitude (appearance) and openness to the supervisory board in matters of fraud, illegal acts, and disagreements with executive directors determine overall audit quality. The independence factors, "whistle blowing/public agent duty," and openness to the public in the audit report (qualified opinion) are not found to be important determinants of overall audit quality. The former dimension (whistle blowing/public agent duty) emphasizes the importance of auditor confidentiality with regard to problems in the company. Related to this finding, a supervisory director in our experience group commented:

Yes the auditor should be able to detect errors and irregularities such as income smoothing, going-concern problems, internal control deficiencies, fraud, illegal acts, and risky investments and transactions. All these are relevant for audit quality. However, the auditor is not entitled to report them to the public. He/she should report the findings on these issues to me (the supervisory board). Otherwise the auditor should resign.

An audit partner also underlined the need for auditor confidentiality:

The detection of errors is important for the supervisory board. The reporting of detected errors to the public, on the other hand, is not appropriate. There has to be certain level of confidence between the executives and supervisory boards. If you are an executive director and you have a disagreement with the auditor and the supervisory board asks the auditor to publish it in the local papers, then what is left of the relationship between you and the auditor? The only way of communication between the auditor and the public is the audit report and other things are to be reported within the company.

The finding that issuing a qualified opinion is not an important determinant of audit quality seems to indicate that supervisory directors expect the auditor to take extra pains to resolve disagreements with management on the financial reports before issuing a qualified opinion. This is perhaps because in the Netherlands supervisory 
directors have a prime responsibility to the company, not to a stakeholder. They may believe that a qualified opinion is a threat to the company's survival or growth.

\section{CONCLUSIONS AND IMPLICATIONS}

The purpose of this study was to investigate the influence of audit quality attributes on the perceptions of supervisory directors' in medium and large corporations in the Netherlands about their auditors' overall quality. Previously, only Dassen (1995) appears to have tested the impact of audit quality attributes on perceptions of overall audit quality. Although Morton (1998) identified similar technical and functional attributes of audit quality, she did not test the impact of these attributes on perceived overall audit quality. This study has revealed that supervisory directors recognize the multidimensional nature of audit quality. A factor analysis of the functional attributes and technical attributes has shown this multidimensionality. Factor analysis of the technical quality attributes produced four dimensions of audit quality: "whistle blowing (public agent)," "integrity in financial reporting process," "detection and reporting of fraud and illegal acts," and independent attitude. The functional audit quality dimensions that resulted from the factor analysis are "reliable audit process," "providing quality insights," "company and industry knowledge," "easy-to-deal-with," and "accessibility."

Three hypotheses directed our investigation of the determinants of overall audit quality. Overall audit quality was hypothesized to be positively influenced by all technical, independence and functional quality dimensions. The regression analysis indicated that supervisory boards base their auditors' overall quality assessment on the technical, functional, and independence dimensions identified in this study. From the technical dimensions, integrity in financial reporting process as well as detection and reporting of fraud and illegal acts influence overall audit quality. From the functional dimensions, auditor service reliability, auditor's company and industry knowledge, his being easy-to-deal-with are the determinants of overall audit quality. And from the independence dimension, auditor's independent appearance and his loyalty to the supervisory board in matters of fraud, illegal acts, and disagreements with company management determine overall audit quality. The auditor's roles in providing quality insights, public agent duty, and openness to the public in the audit report (qualified opinion) are not found to be important determinants of overall audit quality. It appears that the current change in decision authority regarding the audit function from management to supervisory directors at best elevates auditor independence to just one company authority higher (the supervisory directors). This suggests that the comfort of the investing public with the credibility of financial information depends on the 
independence of the supervisory directors themselves.

\section{LIMITATIONS OF THE STUDY}

This study has several limitations, so readers must be cautious in making generalizations. First, we had a small number of sample observations (69 supervisory directors) which may not represent all supervisory directors in the Netherlands. Second, the confidential nature of the auditor-client relationship of the audit profession and the infrequent contact between auditors and supervisory boards make it difficult to elicit more explicit responses for some attributes of audit quality. Finally, multicollinearity between some technical and functional dimensions is one of the limitations caused by the size of the sample because factor analysis could not be performed on all the functional and technical variables simultaneously.

\section{IMPLICATIONS}

In the marketing literature we saw that service quality is evaluated using search, experience, and credence attributes (Bojanic 1991). We argued that the economics of auditing literature defines audit quality mainly in terms of credence attributes. Credence attributes focus on the core outcome of the audit service, which is the detection and reporting of breaches in financial reporting (DeAngelo 1981). However, since these quality dimensions are unobservable to external users, most studies of audit quality use surrogates such as audit firm size and auditor specialization to evaluate audit quality. However, this is simply a conversion of credence attributes to search attributes because these attributes are usually used in the selection of audit firms. Thus, widely used surrogates of audit quality based on the definition in the economics of auditing literature do not allow post-purchase (re)evaluation of audit firms. In this study we used experience attributes to evaluate audit quality, including for the core outcome of the audit service. Consequently, we were able to capture broader dimensions of audit quality involving search, experience, and credence attributes. Therefore, a definition of audit quality based on client's experience appears more relevant and appealing.

Our findings on the determinants of overall audit quality indicated that supervisory directors do not appreciate an auditor who is open to the public about irregularities within their company. This could have an destructive impact on stakeholders' interest if supervisory directors have excessive confidence in their executive directors or if they lose their independence. Investigation of the Enron disaster has shown this to the case. 


\section{FUTURE STUDY}

This study has probably raised as many questions as it has answered. Several studies might answer some of these questions. We make the following suggestions: There is still a significant percentage of variance in overall audit service quality unaccounted for by the quality dimensions identified in this study. A study of the identification of more audit service quality dimensions could narrow this gap. A comparison of clients' perceptions of service quality with those of auditors could add to our knowledge on the extent to which the views of clients are reflected by the service providers. This study has revealed that several dimensions of audit service quality are not significant determinants overall audit quality. Particularly, it is not known why supervisory directors do not appreciate the auditor's openness to the public. Therefore, a qualitative and qualitative study of the investing public's expectation on the auditor's public agent duty could complement our knowledge.

\section{REFERENCES}

Addams, H. L. and Davis, B. (1994). Privately Held Companies Report Reasons for Selecting and Switching Auditors, The CPA Journal, 64, Issue 8, p.38.

Babakus, E. and Boller, G. W. (1992). An Empirical Assessment of the SERVQUAL Scale, Journal of Business Research, 24, 253-268. http://dx.doi.org/10.1016/01482963(92)90022-4

Beattie, V. and Fearnley, S. (1998). Auditor changes and tendering: UK interview evidence, Accounting, Auditing, and Accountability Journal, 11, No. 1, 72-98. http://dx.doi.org/10.1108/09513579810207319

Beattie, V. and Fearnley S. (1995). The Importance of Audit Firm Characteristics and the Drivers of Auditor Change in UK Listed Companies, Accounting and Business Research, 25, No. 100, 227-239. http://dx.doi.org/10.1108/09513579810207319 Bojanic, D. C. (1991). Quality Measurement in Professional Services Firms, Journal of Professional Services Marketing, 7 (2), 27-36. http://dx.doi.org/10.1080/15332969.1991.9985011 Bolton, R. N. and Drew, J.H. (1991). A Multistage Model of Customers' Assessment of Service Quality and Value, Journal of Consumer Research, 17, 375-384.

Boshoff, C., Mels, G. and Nel, D. (1994). The Relative Influence of Service Quality in the Banking Industry, South African Journal of Business Management, (March), 25, Issue 1.

Brown, S. W. and Swartz, T. A. (1989), A Gap Analysis of Professional Service Quality, Journal of Marketing, 53, No 2, 92-98 http://dx.doi.org/10.2307/1251416

Peter, J. P., Churchill Jr., G. A., and Brown, T. J. (1993). Caution in the Use of Difference Scores in Consumer Research, Journal of Consumer Research, 19, Issue 4, 655-662. http://dx.doi.org/10.1086/209329 
Carcello, J. V., Hermanson, R. H., and McGrath, N. T., (1992). Audit Quality Attributes: The Perceptions of Audit Partners, Preparers, and Financial Statement Users, Auditing: A Journal of Practice and Theory, (Spring), 11, No. 1, 1-15.

Carson, E., Fargher, N.L., Geiger, M.A., Lennox, C.S., Raghunandan, K. and Willekens, M. (2013). Audit reporting for going-concern uncertainty: A research synthesis. Auditing: A Journal of Practice and Theory, 32(1): 353-384. http://dx.doi.org/10.2308/ajpt-50324

Causholli, M. and Knechel, W.R. (2012). An examination of the credence attributes of an audit, Accounting Horizons, 26 (4): 631-656. http://dx.doi.org/10.2308/acch-50265

Churchill, Jr. G. A. (1979). A Paradigm for Developing Better Measures of Marketing Constructs, Journal of Marketing Research, XVI, 64-73. http://dx.doi.org/10.2307/3150876

Cronin, J. J., Brady, M. K. and Hult G. T. M. (2000). Assessing the Effects of Quality, Value, and Satisfaction on Consumer Behavioural Intentions in Service Environments, Journal of Retailing, 76 (2), 193-218.

Cronin, J. J. and Taylor, S. A. (1992). Measuring Service Quality: A Re-examination and Extension, Journal of Marketing, 56, 55-68.

Dassen, R. J. M., (1995). Audit Quality: An Empirical Study of the Attributes and Determinants of Audit Quality Perceptions, Ph.D. dissertation, University of Limburg.

DeAngelo, L. E. (1981a). Auditor Size and Audit Quality, Journal of Accounting and Economics, 3, Issue 3, 183-199. http://dx.doi.org/10.1016/0165-4101(81)90002-1

DeFond, M.L., and Zhang, J. (2014). A review of archival auditing research. Journal of $\begin{array}{lllll}\text { Accounting } & \text { and } & \text { Economics, } & 58 & \text { (2), }\end{array}$ http://dx.doi.org/10.1016/j.jacceco.2014.09.002

de Vaus, D. A. (1996). Surveys in Social Research, Fourth Edition, UCL Press Ltd., London. Donovan, J., Frankel, R., Lee, J., Martin, X. and Seo, H. (2014). Issues raised by studying DeFond and Zhang: What should audit researchers do? Journal of Accounting and Economics, 58(2): 327-228. http://dx.doi.org/10.1016/j.jacceco.2014.09.001

Duff, A. (2004). Auditqual, Dimensions of Audit Quality, The Institute of Chartered Accountants of Scotland, Antony Rowe Ltd, Great Britain.

Elliott, R. K. and Parlays, D. M. (1997). Are You Ready for New Assurance Services? Journal of Accountancy, 183, Issue 6, 47-50.

Francis J. R. (2004). What do we know about audit quality?, British Accounting Review, 36, No. 4, 345-368 http://dx.doi.org/10.1016/j.bar.2004.09.003

Francis, B. (1996), SERVQUAL, Review, Critique, Research Agenda, European Journal of Marketing, 30, Issue 1, 8-25.

Grónroos, C. (1990). Service Marketing and Management: Moments of Truth in Service Competition, D. C. Heath-Lexington Books, Lexington, MS. 
Grónroos, C. (1984). A Service Quality Model and its Marketing Implications, European Journal of Marketing, No. 4, 36-44.

Herrbach, O. (2001). Audit Quality, Auditor Behaviour, and the Psychological Contact, The European Accounting Review, 10: 4, 787-802.

Jensen, M. C. and Meckling, W. H. (1976). Theory of the Firm: Managerial Behaviour, Agency Costs, and Ownership Structure, Journal of Financial Economics, 3, 305-360.

Kim, J. and Meuller, C. W. (1994). Factor analysis and Related Techniques, Edited by M. S. Lewis-Beck, Sage Publications Inc.

Knapp, M. C. (1991). Factors that Audit Committee Members Use as Surrogates for Audit Quality, Auditing: A Journal of Practice and Theory, 10, No. 1, 35-51.

Krishnan, J. and Schauer, P. C. (2000). The Differentiation of Quality Among Auditors: Evidence from the Non-for-Profit Sector, Auditing: A Journal of Practice and Theory, 19. No. 2, 9-25. http://dx.doi.org/10.2308/aud.2000.19.2.9

Lehtinen, U. and Lehtinen, J. R. (1991). Two Approaches to Service Quality Dimensions, The Service Industries Journal, 11, No. 3, 287-303. http://dx.doi.org/10.1080/02642069100000047

Lu, C., Berchoux, C., Marek, M. W., and Chen, B. (2015). Service Quality and Customer Satisfaction: Qualitative Research Implications for Luxury Hotels, International Journal of Culture, Tourism and Hospitality Research, 9(2). http://dx.doi.org/10.1108/IJCTHR10-2014-0087

Markovic, S. and Raspor, S. (2010). Measuring Perceived Service Quality Using Servqual: A Case Study of the Croatian Hotel Industry, Management, 5 (3), 195-209.

Morton, A.M. (1998). Audit Service Quality: An Empirical Investigation, PhD. Dissertation, University of Sydney.

Mosahab, R., Mahamad, O. and Ramayah, T. (2010). Service Quality, Customer Satisfaction and Loyalty: A Test of Mediation, International Business Research, 3, No. 4, 72-80.

Parasuraman, A., Zeithaml, V. A., and Berry, L. L. (1991), Refinement and Reassessment of the SERVQUAL Scale, Journal of Retailing, 67, No. 4, 420-450.

Parasuraman, A., Zeithaml, V. A., and Berry, L. L. (1988). SERVQUAL: A Multiple-Item Scale for Measuring Consumer Perceptions of Service Quality, Journal of Retailing, 64, No.1, 12-40.

Parasuraman, A., Zeithaml, V. A., and Berry, L. L. (1985). A Conceptual Model of Service Quality: Implications for Future Study, Journal of Marketing, 49, (Fall), 41-50.

Reeves, C. A. and Bednar, D. A. (1994). Defining Quality: Alternatives and Implications, Academy of Management Review, 19, No. 3, 419-445. http://dx.doi.org/10.5465/amr.1994.9412271805

Richard, M. D. and Allaway, A. W. (1993). Service Quality Attributes and Choice Behaviour, 
$\begin{array}{lllll}\text { Journal of } & \text { Service } & \text { Marketing, } & \text { 59-68. }\end{array}$ http://dx.doi.org/10.1108/08876049310026105

Saleh, F. and Ryan, C. (1991). Analysing Service Quality in the Hospitality Industry Using the SERVQUAL Model, Service Industries Journal, 11, (July), 324-343. http://dx.doi.org/10.1080/02642069100000049

Sanjuq, G. (2014). The Impact of Service Quality Delivery on Customer Satisfaction in the Banking Sector in Riyadh, Saudi Arabia, 1International Journal of Business Administration, 5, No. 4, 77-84. http://dx.doi.org/10.5430/ijba.v5n4p77

Smith, R. (2003). Audit Committees, Combined Code Guidance, The Financial Reporting Council, UK.

Stank, T. P., Goldsby, T. J. and Vickery, S. K. (1999). Effects of Service Supplier Performance on Satisfaction and Loyalty of Store Managers in the Fast Food Industry, Journal of Operations Management, 17, 429-447. http://dx.doi.org/10.1016/S02726963(98)00052-7

Sweeney, J. C., Soutar, G. N. and Johnson, L. W. (1997). Retail Service Quality and Perceived Value, Journal of retailing and Consumer Services, 4, No. 1, 39-48. http://dx.doi.org/10.1016/S0969-6989(96)00017-3

Tabaksblat Committee (2003). The Dutch Corporate Governance Code: principles of good corporate governance and best practice provisions; www.commissiecorporategovernance.nl.

Teas, R. K. (1993). Consumer Expectations and Measurement of Perceived Service Quality, Journal of Professional Service Marketing, 8, No. 2, 33-53. http://dx.doi.org/10.1080/15332969.1993.9985048

Tendello, B., V. and Vanstraelen, A. (2005). Earnings Management and Audit Quality in Europe: Evidence from the Private Client Segment market, A Paper Presented at the 3rd EARNet Conference, Amsterdam.

van Raak, J. and Thürheimer U. (2016). Opportunities to improve the measurement of audit quality: a call for collaboration between the profession and academics, Maandblad voor Accountancy en Bedrijfseconomie, 90, (9), 352-358.

Warming-Rasmussen, B. and Jensen, L. (1998). Quality Dimensions in External Audit Services-An External User Perspective, The European Accounting Review, 7, No. 1, 6582. http://dx.doi.org/10.1080/096381898336583

Watkins, A. L., Hillison, W. and Morecroft, S. E., (2004). Audit quality: A synthesis of theory and empirical evidence, Journal of Accounting Literature, 23, 153-193.

Watts, R. L. and Zimmerman, J. L. (1981). The Market for Independence and Independent Auditors, Working Paper, University of Rochester.

Woo, K. and Ennew, C. T. (2005). Measuring Business-to-Business Professional Service 
Quality and its Consequences, Journal of Business Research, 58, 1178-1185. http://dx.doi.org/10.1016/j.jbusres.2004.05.003

Wooten, T. C. (2003). Research about Audit Quality, The CPA Journal, 73, Issue 1, 48-51.

Zeithaml, V. A., Parasuraman, A. and Malhotra, A. (2002). 'Service quality delivery through web sites: a critical review of extant knowledge', Journal of the Academy of marketing Science, 30(4), 362-75. http://dx.doi.org/10.1177/009207002236911

Zeithaml, V. A. (2000). 'Service quality, profitability, and the economic worth of customers: what we know and what we need to learn', Journal of the Academy of Marketing Science, 28 (1), 67-85. http://dx.doi.org/10.1177/0092070300281007

Zeithaml, V. A., Berry, L. L. and Parasuraman, A. (1996). The behavioural Consequences of Service Quality, Journal of Marketing, 60 (April), 31-4

Zeithaml, V. A., Parasuraman, A. and Berry, L. L. (1990). Delivering Quality Service, New York, Free Press.

Zeithaml, V. A., Berry, L. L. and Parasuraman, A. (1988). A Communication and Control Processes in the Delivery of Service Quality, Journal of Marketing, 52, 35-48. http://dx.doi.org/10.2307/1251263 


\section{APPENDIX 1}

a) Our external auditors maintain error-free and up-to-date audit working papers.

b) Our external auditors are reliable in handling my company's service problems.

c) Our external auditors provide service by an agreed deadline.

d) Our external auditors are responsive to my needs as a supervisory director.

e) The audit partner has the knowledge to answer my questions related to the audit and financial reporting.

f) Our external auditors are accessible to the supervisory board members whenever the need arises (through telephone, electronic media, etc.)

g) The audit partner actively participates in the planning and execution of the audit.

h) There is frequent (three or four times a year) meetings between my company's audit partner and the supervisory board.

i) Our external auditors provide for at least once a year private session meeting with the supervisory board without the presence of executive directors.

j) The audit partner has the ability to express himself/herself clearly.

k) Our external auditors are pro-active in giving the executive and supervisory board unsolicited advice on corporate governance.

1) Our external auditors have knowledge of the internal and external environment of my company.

m) The audit firm makes use of its international contacts and resources to service my needs.

n) Our external auditors make sufficient use of my company's internal audit as part of their audit process.

o) Our external auditors are able to detect material errors in the financial statements.

p) Our external auditors report material errors in the financial statements to the supervisory board.

q) Our external auditors publicly report unadjusted material errors in the financial statements.

r) Our external auditors are able to detect earnings management in the financial statements.

s) Our external auditors report earnings management in the financial statements to the supervisory board.

t) Our external auditors publicly report unadjusted earnings management in the financial statements.

u) Our external auditors are able to detect going-concern problems.

v) Our external auditors report going-concern problems to the supervisory board.

w) Our external auditors publicly report going-concern problems.

$\mathrm{x})$ Our external auditors are able to detect material deficiencies in internal control.

y) Our external auditors report material deficiencies in internal control to the supervisory board.

z) Our external auditors publicly report material deficiencies in internal control.

aa) Our external auditors are able to detect material employee fraud. 


\section{APPENDIX 1 (continued)}

bb) Our external auditors report material employee fraud to the supervisory board.

cc) Our external auditors publicly report material employee fraud.

dd) Our external auditors are able to detect material management fraud.

ee) Our external auditors report material management fraud to the supervisory board.

ff) Our external auditors publicly report material management fraud.

gg) Our external auditors are able to detect illegal acts related to the core business of the company.

hh) Our external auditors report illegal acts to the supervisory board.

ii) Our external auditors publicly report illegal acts.

jj) Our external auditors have a high level of integrity.

kk) Our external auditors have a professionally sceptical attitude towards company management.

11) Our external auditors are independent of all stakeholders of our company.

$\mathrm{mm}$ ) Our external auditors have regulatory knowledge with regard to corporate transparency (such as stock exchange regulations, accounting rules, cartel, etc.)

$\mathrm{nn}$ ) The audit firm has provisions to keep our company up-to-date on new developments in financial reporting.

oo) The audit firm has formal quality control procedures to detect substandard audit performance and to improve quality.

pp) The audit firm has a good overall reputation.

qq) Our external auditors are specialists in our industry.

rr) Our external auditors provide us with comments on the quality of the executives (CEO, CFO, etc).

ss) Our external auditors give us comments on the quality of forecasts and targets set by the executives.

tt) Our external auditors provide us with benchmark comparisons on the quality of our company's internal control.

uu) Our external auditors have excellent audit effectiveness in terms of accomplishing planned audit work.

vv) Our external auditors provide us with early warnings of company problems.

ww) The audit firm is responsive to the needs of our company's executive directors.

$\mathrm{xx}$ ) Our external auditors are accessible to the executive board whenever the need arises (through telephone, electronic media, etc.)

yy) Our external auditors charge a reasonable amount of audit fee.

zz) Our external auditors provide us services other than the financial statements audit. 
APPENDIX 2

Multicollinearity Indications among Some Technical and Functional Factors

\begin{tabular}{|c|c|c|c|c|c|c|c|c|c|c|c|}
\hline & 1 & 2 & 3 & 4 & 5 & 6 & 7 & 8 & 9 & 101 & 11 \\
\hline 1 Reliable audit process & - & & & & & & & & & & \\
\hline $\begin{array}{l}2 \text { Company and industry } \\
\text { knowledge }\end{array}$ &, 000 & - & & & & & & & & & \\
\hline 3 Easy-to-deal-with & 000 &, 000 & - & & & & & & & & \\
\hline 4 Providing quality insights &, 000 &, 000 &, 000 & - & & & & & & & \\
\hline 5 Accessibility &, 000 &, 000 &, 000 & 000 & - & & & & & & \\
\hline 6 Public agent/Whistle blowing &,- 075 &,- 083 &, 082 &, $536 * *$ &,- 134 & - & & & & & \\
\hline $\begin{array}{l}7 \text { Detection and reporting of fraud } \\
\text { and illegal acts }\end{array}$ & ,090 & , 188 &, 104 &, $391 * *$ & ,090 &, 000 & - & & & & \\
\hline $\begin{array}{l}8 \text { Integrity in financial reporting } \\
\text { process }\end{array}$ &, $369 * *$ &, 137 &, $593 * *$ & ,072 , &, $382 * *$ & ${ }^{k}, 000$ &, 000 & - & & & \\
\hline 9 Independent attitude & $354 * *$ & ,495** &,- 056 &,- 029 &,- 082 &, 000 &, 000 &, 000 & - & & \\
\hline 10Qualified opinion &,- 005 & ,155 &, 051 &, 130 &, $260 *$ &, $058-$ &,- 018 & ,189 &,- 071 & - & \\
\hline $\begin{array}{l}\text { 11Bring to the attention of } \\
\text { supervisory directors }\end{array}$ & ,092 & ,135 & ,235 & ,232 &, $269 *$ & ,087, &, 162 & $327 * *$ & 021, & $387 * *$ & \\
\hline
\end{tabular}

** Correlation is significant at the 0.01 level (2-tailed).

* Correlation is significant at the 0.05 level (2-tailed).

\section{ENDNOTES}

${ }^{1}$ In a two-tier board system, the board of directors are often called Supervisory Boards.

${ }^{2}$ For example, in the modernized $8^{\text {th }}$ Directive of the European Commission it is required that audit committees $^{2}$ should play a central role in selecting the statutory auditor (audit firm) and proposing its appointment to the general meeting of shareholders of the audited entity. Additionally, audit committees are also required to review and monitor the independence of the auditor. These proposals, however, are not new. In the US, the Sarbanes-Oxley Act of 2002 requires the auditor to notify the audit committee about critical accounting policies and practices to be used, alternative treatments of financial information, accounting disagreements with management, and other relevant communications between the auditor and management. Also European self-regulatory initiatives, such as the British Combined Code (2003) and the Dutch Corporate Governance Code (2004), contain similar provisions.

${ }^{3}$ Economics of auditing researches have argued that larger audit firms provide higher audit quality compared to small audit firms (e.g., DeAngelo 1981). Numerous empirical studies support this argument. 
${ }^{4}$ There is no absolute rule as to how high a variable's correlation coefficient should be before it is said to load on a factor. However, it would be unusual to accept variables whose correlation coefficients are lower than 0.30 (Hair et al. 1998; de Vaus 1996).

${ }^{5}$ For more information on this, see Hair et al. (1998: 100-103).

${ }^{6}$ A value of 0.7 shows that the correlations are sufficiently enough to make factor analysis suitable. If the value is between 0.5 and 0.69 factor analysis is still possible but care needs to be taken in the interpretation of the factors. A value of less than 0.5 means that the set of variables is not suitable for factor analysis (de Vaus 1996). 